Western University

Scholarship@Western

Aboriginal Policy Research Consortium International (APRCi)

2000

\title{
Wildlife and world views: Australian attitudes toward wildlife
}

Heather J.Aslin

David H. Bennett

Follow this and additional works at: https://ir.lib.uwo.ca/aprci

Part of the Sociology of Culture Commons

Citation of this paper:

Aslin, Heather J. and Bennett, David H., "Wildlife and world views: Australian attitudes toward wildlife" (2000). Aboriginal Policy Research Consortium International (APRCi). 310.

https://ir.lib.uwo.ca/aprci/310 
This article was downloaded by: [University of Western Ontario]

On: 20 December 2012, At: 11:39

Publisher: Routledge

Informa Ltd Registered in England and Wales Registered Number:

1072954 Registered office: Mortimer House, 37-41 Mortimer Street, London W1T 3J H, UK

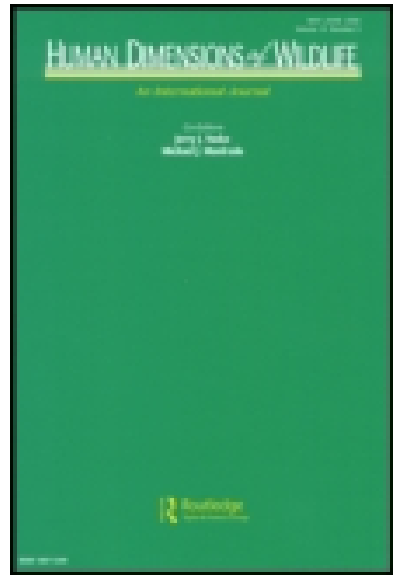

\section{Human Dimensions of Wildlife: An International J ournal}

Publication details, including instructions for authors and subscription information: http:// www. tandfonline.com/loi/ uhdw20

\section{Wildlife and world views: Australian attitudes toward wildlife}

\author{
Heather J. Aslin ${ }^{a} \&$ David H. Bennett ${ }^{b}$ \\ a Bureau of Rural Sciences \\ ${ }^{b}$ Australian Academy of the Humanities \\ Version of record first published: 22 Sep 2008.
}

To cite this article: Heather J . Aslin \& David H. Bennett (2000): Wildlife and world views: Australian attitudes toward wildlife, Human Dimensions of Wildlife: An International J ournal, 5:2, 15-35

To link to this article: http:/ / dx.doi.org/ 10.1080/ 10871200009359177

\section{PLEASE SCROLL DOWN FOR ARTICLE}

Full terms and conditions of use: http://www.tandfonline.com/page/ terms-and-conditions

This article may be used for research, teaching, and private study purposes. Any substantial or systematic reproduction, redistribution, reselling, loan, sub-licensing, systematic supply, or distribution in any form to anyone is expressly forbidden.

The publisher does not give any warranty express or implied or make any representation that the contents will be complete or accurate or up to date. The accuracy of any instructions, formulae, and drug doses should be independently verified with primary sources. The publisher shall not be liable for any loss, actions, claims, proceedings, demand, or 

indirectly in connection with or arising out of the use of this material. 


\title{
Wildlife and world views: Australian attitudes toward wildlife
}

\author{
Heather J. Aslin \\ Bureau of Rural Sciences \\ David H. Bennett \\ Australian Academy of the Humanities
}

\begin{abstract}
Research in a number of western and non-western cultures suggests there are only a limited number of basic orientations toward other species. In the broadest sense, these can be related to fundamental cultural assumptions about what the world is like - world views, world metaphors or cosmologies - and how other species are represented as a result of these assumptions.
\end{abstract}

In this paper we explore our topic in relation to two cultural traditions those of Aboriginal Australians and Anglo-Australians. We discuss how the differing world views represented in these cultures relate to wildlife attitudes. Aboriginal sociery before British settlement of Australia shared a substantial consensus about what other animals were like and what was acceptable or unacceptable behavior toward animals. This is reflected in the Aboriginal concept of 'country', Aboriginal totemic systems, and the responsibilities Aboriginal people have by virtue of 'belonging to country'. By contrast, Anglo-Australian society, with its roots in a diverse GrecoRoman philosophical tradition now spread around the world, and highly fragmented into subcultures, shows little agreement about appropriate behavior towards other species. Not only this, but the often abstract and distanced nature of western interests in wildlife means that many AngloAustralians, particularly those living in urban areas, have no personal connections to or responsibilities for wildlife in place or in country.

We also discuss how the different cultural categories and conceptions of wildlife used by Aboriginal and Anglo-Australians influence their attitudes and behavior. In particular we discuss the terms 'native', 'exotic' and 'feral'. As a specific example, we consider attitudes toward the feral cat in Australia and how they differ between the two cultural systems. In conclusion, we compare wildlife management concepts in the two cultures.

Keywords: attitudes, values, world views, Aboriginal, Australia 


\section{Introduction}

The goals of the 1999 International Symposium on Society and Resource Management, held in Brisbane, Australia, stated that there was a need to:

- enhance insight into the diverse social and cultural understanding of the environment and the incorporation of diverse knowledge systems into resource issue dialogues; and

- facilitate interaction and integration among different social and biological science approaches in dealing with natural resource issues.

These objectives relate to wildlife issues if wildlife is considered to be a 'resource'. Not everyone would be happy with this way of framing wildlife issues. Those people who believe that other living creatures have intrinsic value may object to this terminology. Intrinsic value is taken to mean that something has a value beyond any value it has for a user, or as a means to some other value or end. This does not mean that it cannot be used but that it cannot be treated solely as a means to an end. It must also be treated as an end-in-itself (Sylvan \& Bennett, 1994; Bennett, 1995). In the case of wildlife, the notion of intrinsic value implies that humans should not treat wildlife as valuable only when it has a benefit to some individual or group of humans, rather that humans must extend moral considerations to wildlife even when the wildlife in question is not useful to humans.

Setting this qualification aside, in Australian society there is a wide range of social and cultural perspectives, sometimes termed world views, arising from the nation's social and cultural history. There are the perspectives of Aboriginal and Torres Strait Islander people - the 'first people' of Australia - who developed unique cultures and adaptations to the Australian environment largely in isolation from other cultural influences until British setrlement began officially in 1788 (see for example Kohen, 1995). The size of the Aboriginal and Torres Strait Islander population at the time of British settlement is debated (estimates ranging from 300,000 to one million), but in the 1996 Australian Census of Population and Housing nearly 390,000 Australians identified themselves as being of Aboriginal or Torres Strait Islander descent (Australian Bureau of Statistics, 1999a). Indigenous Australians hold about $15 \%$ of Australia's land area, mainly in the arid zone (Aboriginal and Torres Strait Islander Commission, 1997).

On the other hand, there is today's dominant Anglo-Australian culture with its origins in Britain and Europe. More recently, a range of new cultural and ethnic perspectives have been brought to Australia as a result of the large post-World War II migration program. From the 1996 Census, 3.9 million of the estimated total Australian population of 18.5 million people had been born overseas in one of more than 200 countries (Australian Bureau of Statistics, 1999b). 
In this paper we aim to demonstrate some implications for wildlife issues arising from an appreciation and acknowledgment of the differing social and cultural systems represented in Australia. We will do this by comparing the perspectives of Australian Aboriginal people and those of non-indigenous Australians, primarily those from Anglo-Australian backgrounds. The perspectives of Torres Strait Islander people, who have a culture based largely on the sea and its resources, are not addressed in this paper.

Country and custom in Aboriginal Australia

An essential basis of the Aboriginal world view is the concept of 'country'. The word 'country' in an Aboriginal context:

$\ldots$ is a place that gives and receives life. Not just imagined or represented, it is lived in and lived with. Country in Aboriginal English is not only a common noun but also a proper noun (Rose, 1996, p. 7).

It differs greatly from the Western concept of a nation state and is much more geographically and socially specific. Aboriginal people relate and belong to a particular area that is their country. From this sense of belonging to country flows a whole suite of responsibilities relating to the land, its physical features, and the animals and plants inhabiting the land. Aboriginal people have social obligations to participate actively in 'caring for country' (Collins, Klomp \& Birckhead, 1996; Young, Ross, Johnson \& Kesteven, 1991).

These responsibilities, the equivalent of socially-prescribed and socially-sanctioned attitudes, values and codes of behavior, are set out in Aboriginal customary law. While the exact relationship between a given person and a given species depends on the law and custom of the group to which the individual belongs, there are certain similarities across Aboriginal customary law. For instance, the relationships can be expressed in terms of totemism:

What is meant by totemism in Aboriginal Australia is always a mystical connection, expressed by symbolic devices and maintained by rules, between living persons, whether as individuals or as groups or as stocks, and other existents - their 'totems' - within an ontology of life that in Aboriginal understanding depends for order and continuity on maintaining the identities and associations which exemplify the connection (Stanner, 1979, pp. 127-128).

Any given country has a characteristic set of totemic species and relationships. These derive from the Aboriginal world view or cosmology in which the country and the animals and plants living in it provide a record of ancestral beings and their activities. These beings, considered to be both human and animal simultaneously, were active in a creative period called the 'Dreamtime' in English, and their spirits continue to be present in the 
landscape. Collectively the body of beliefs about the formation of the earth, its plants and animals, and people's relationships to them, are referred to as the 'Dreaming' or as indigenous 'customary law'. Present-day Aboriginal people are the descendants of the ancestral beings and have totemic relationships to particular ancestral beings and the animals, plants or other natural phenomena associated with them. Totemism also provides a method for persons from outside a given Aboriginal group to identify that group and their relationship to that group, and provides a common or group property for those within the group. So, the totem is both a symbolic identification and a cohesion principle.

In an effort to make these relationships somewhat more accessible to non-Aboriginal people, anthropologist John Von Sturmer has compared the symbolic identification and cohesion principle of totemism to:

... a football team which owns a football ground, and has a particular guernsey [jersey] to distinguish it from opposition teams. The team may choose to call itself the 'Tigers' and therefore select a guernsey made up of orange and black stripes; ... the area from which the team recruits its members may be called 'Tiger Territory', the team ground may be described as the 'Home of the Tigers' (Von Sturmer, 1978, p. 503).

On this interpretation of totemism, the totem becomes the team mascot and name, and the clan territory or 'estate' becomes the football ground. There is cohesion within the team and defined relationships to other teams, which are all in the same league. Furthermore, this connection within and among groups connects the individual and the group to the country or territory:

The effect of the totemic complex as a whole is to parcel out, on a kind of distributive plan, all the non-human entities made or recognized by the ancestors, and given relevance one to another, that is set up in a moral system (Stanner, 1960, p. 252).

This parcelling out of all 'non-human entities' is a foundation of Aboriginal relations to other species.

In relation to Aboriginal cultural links to animals and plants, Deborah Bird Rose points out:

To promote the well-being of animals and plants it is necessary that the appropriate rituals be performed by the correct people (that is, the people whose totem or Dreaming that species is or whose country it is by other forms of relationship) (Rose, 1996, p. 57). fauna:

Regarding the relationship among people, their country, and native 
... indigenous Australians may have a special interest in the commercial utilization of native wildlife, arising from ... ethical and religious associations with species and places based on prior occupation of the Australian continent. Many indigenous people see native wildlife as their preserve and responsibility (Altman, Roach \& Liddle, 1997, p. 2).

Aboriginal relationships and responsibilities to country are passed on from generation to generation in traditional indigenous societies as younger generations learn from their elders in socially-appropriate ways and contexts, maintaining cultural continuity and corresponding continuity in land management practices. Aboriginal elder, Mick Dodson, points out two aspects of living in and living with country:

Our traditional relationship to land is profoundly spiritual. It is also profoundly practical. ... For instance, hunting, fishing and harvesting are neither merely economic [n] or cultural activities. As older people walk the country they teach the young; they tell the stories and teach the responsibilities (Dodson, 1997, p. 43).

These practices persisted for many thousands of years in Aboriginal society and continue today, despite European settlement of Australia and many Aboriginal people being killed, dying from introduced diseases, or being physically displaced from their country.

\section{Nation and culture in Anglo-Australian society}

Anglo-Australians have their cultural origins primarily in Britain - the 'old country'. Hence, when the first British settlers came to Australia, the Australian landscape and its flora and fauna were unfamiliar and 'exotic' literally 'of foreign origin or character' or alternatively 'strikingly unusual or colorful in appearance or effect' (Macquarie Concise Dictionary, 1988, p. 329). Home was half a world away, and the settlers (who were exotic themselves) had a great desire to make their new country more homelike by introducing familiar plants and animals for utilitarian, sporting, or aesthetic purposes. The stories of these introductions and acclimatizations have been told in books that have become Australian zoological classics (Rolls, 1969; Marshall, 1966; Lines, 1991; Flannery, 1994).

Today, modern western societies (of which Anglo-Australian society is an example) are extremely large in comparison with the indigenous societies they have often overtaken or displaced. Modern western societies are also fragmented into many highly specialized subcultures. Socio-demographic factors like gender, occupation, income, social class, age, geographical location, and ethnic origin, all provide the basis for unique subcultures to develop and for people belonging to these subcultures to become highly differentiated in lifestyles, habits, values, attitudes, vocabulary, and ways of 
thinking. This differentiation needs to be taken into account in all social research conducted in western societies, including research on attitudes and values toward wildlife.

Bearing in mind this social complexity, in 1994 and 1995, Aslin (1996) conducted semi-structured interviews to record wildlife attitudes of Australians representing a wide range of wildlife occupations and interests. Also, focus group discussions were conducted with people from the general population, differentiated by gender, occupation, age and location (Aslin, 1996). When interviewees and focus group members were asked what had been the major influences on their attitudes toward wildlife, many identified learning experiences related to family or childhood situations. One woman commented 'It's the way you're brought up', and 'It's all about conditioning'. Some interviewees did not hesitate to attribute their attitudes to a parent's or grandparent's influence. Focus group members also described formative events with their parents, grandparents, or other significant individuals in their lives; or referred to the influences of Christian religious teaching or to their schooling. These are examples of childhood and family socialization experiences typical of western cultures (Parsons, 1991).

The importance of learning from family members in Australian society parallels the way indigenous peoples learn culturally-appropriate values, attitudes, and behaviors regarding other species from their parents and elders. But in non-Aboriginal society, people may learn few specific behaviors toward other species, and they are not as a matter of tradition or custom necessarily assigned any responsibilities toward country or toward species. This is particularly the case for urban people who are distanced from the natural environment and wildlife. For some Aboriginal people, living in an urban situation is the equivalent of living in 'dead country'. For citydwellers especially, there is no equivalent to the Aboriginal concept of belonging to country and the obligations that this entails, nor of totemic relationships and responsibilities. Instead, some urban Australians have developed an interest in wildlife through early experiences and personal preferences, and via exposure to highly specialized occupations, organizations and interest groups focusing to some degree on wildlife. Urban Australians can choose which experiences to pursue, based on their value systems, personal aptitudes, and aspirations. Their choices and connections to wildlife (if they have any at all) may stem from personal preferences rather than from any necessary social obligations.

The fact that this personal discretion is possible relates to the fact that the varying occupations, organizations and interest groups to which westerners belong often have an abstract conceptual basis. This conceptual basis lies in western knowledge systems, philosophies, religions, and histori- 
cal traditions, and their expression in contemporary societies. For example, important conceptual bases for different wildlife attitude and value positions include modern science and the legacy of influential European philosophers like Descartes and Bacon; the varied strands of Greco-Roman philosophy and ethics more generally; the Christian religion; the European and North American hunting traditions; and recent social phenomena like environmentalism, the wilderness movement, and the animal rights movement (Glacken, 1967; Bulbeck, 1996). These conceptual bases may not lead to any specific focus on plants and animals 'in place' or 'in country'.

The complex western social structure has no real counterpart in indigenous societies because western society is so much larger and more widely dispersed geographically than any indigenous society. Western social structure stems from a diffuse and in some senses incoherent cultural history incorporating a range of incompatible world views or world metaphors (Pepper, 1957), rather than a unified tradition that has evolved in relative isolation for millennia. British philosopher Mary Midgley comments that western culture is 'not a single culture at all, but a debating-ground, not a monolith but a fertile confused jungle of sources' (Midgley, 1978, p. 295).

In addressing western social structures relevant to wildlife, Kellert (1976, 1993), Kellert \& Berry (1980), Kellert \& Clark (1991), Kellert \& Wilson (1993), Schulz (1986), Tober (1989), and Orlans (1993) have provided structural analyses of wildlife interest groups and sectors in western societies. The range of wildlife-related organizations and interest groups in western societies and the attitudes they hold, broadly correspond to the categories of basic values about wildlife originally developed by Kellert (1976) and subsequently refined. For the United States' population, Kellert $(1976,1993 \mathrm{~b})$, developed a typology of basic values including naturalistic, ecologistic-scientific, humanistic, moralistic, aesthetic, utilitarian, dominionistic and negativistic. These value categories can also be related to typologies of environmental value positions (Fox, 1990; Sylvan $\&$ Bennett, 1994) and to value categories used by ecological economists. For example, ecological economists may distinguish categories like direct-use values (utilitarian), recreational and aesthetic values, indirect-use values (ecologistic-scientific, naturalistic), option or bequest values (could relate to any types of future direct or indirect uses), and existence and ethical values (humanistic, moralistic) (Pearce \& Turner, 1990; Krutilla \& Fisher, 1985).

When the broad correspondence between wildlife value categories and the range of wildlife organizations or interest groups is recognized, it becomes clear that the existence of different value positions is mirrored in a social structure. This social structure is historically-derived but continually evolving, and transcends the lives of individuals (Giddens, 1984). It exists for wildlife interests just as it does for a myriad other social interests. 
This pre-existing social structuring of wildlife interests influences present generations as value orientations characteristic of particular organizations or interest groups are passed on to successive generations through generalized social learning processes. In some cases, people are influenced directly as they join specific social groups that are part of the broader social structure and learn these groups' orientations 'from the inside'. In these ways, the historically-derived social structure of wildlife interests has a major influence on shaping the range of wildlife values and attitudes held in today's western societies (Aslin, 1996).

The relevance of the existing social structure of wildlife organizations in shaping wildlife values was recognized by Aslin's (1996) interviewees who highlighted the significance of their current workplace context, work role and workplace colleagues in influencing their value-orientations, attitudes, and behaviors towards wildlife. Because many Westerners spend a substantial portion of their lives in paid work, the attitude and value positions espoused by workplace organizations are becoming increasingly important influences. This is one aspect of the rise of 'corporate culture' in the postmodern age (Saul, 1997) that deserves further study.

In terms of moral obligations to other species, parallels in nonindigenous culture to the relationships and responsibilities that indigenous people have to country and to totem are difficult to find. It has been suggested that non-indigenous Australians are striving to develop a 'land ethic' that sets out guidelines for using land and its components sustainably, and this has some similarities to a moral system set up to care for country (Roberts, 1995). National commitments to ecologically sustainable development and a strategy for conservation of biological diversity, as well as to international agreements like the Biodiversity Convention and the Convention on Trade in Endangered Species, represent moral and ethical obligations to wildlife made by Australian governments, both State and Federal, on behalf of their citizens. These national commitments can be seen as reflecting a form of social consensus about how wildlife should be treated, but their implications for the behavior of most Australians are difficult to identify because of their abstract nature.

Native, exotic and feral

We would now like to turn to some more detailed examples of the implications that cross-cultural comparisons have for understanding Australian attitudes and behavior toward wildlife.

The first implication relates to some basic categories used to classify other species, particularly animals - the categories 'native', 'exotic', and 'feral'. This is, in a sense, a discussion of how the metaphorical parcelling out of non-human entities in Anglo-Australian society compares with that 
in traditional Aboriginal society, and delineates how the implicit AngloAustralian moral system for behavior towards wildlife compares with the Aboriginal one.

In the early days of European settlement of Australia, the people and animals from the 'old country' were often allies and friends, while Aboriginal people and indigenous plants and animals were unknown or unfamiliar, and possibly hostile or dangerous. Now the wheel has turned for many Anglo-Australians and they have reversed their judgements to provide a new type of social consensus. The term 'exotic' is now often applied to the animals and plants introduced by the early British settlers, which in the wild state are now the feral and the unwanted. Conversely, the 'native' is that which properly belongs, is adapted to Australian ecosystems, and needs protecting from 'alien invasions'. There has been a complete reversal of meaning and value corresponding to a shift in a metaphorical vantage point. This shift has been influenced by accumulating knowledge of the effects that introduced species have had on Australian ecosystems and Australian agriculture. Previously, Anglo-Australians were looking out metaphorically from a vantage point in Britain or Europe: now their vantage point is Australia. The plants and animals that once made an alien country feel more like home for exiled British convicts and newly-arrived settlers are now seen as out of place because the descendants of these settlers now consider themselves to be Australians. The continent's unique flora and fauna now symbolize home and national identity. In a very similar way to Aboriginal totemism, the better-known native animals and plants have become symbols of Australian nationhood and part of a cohesion principle for many Australians (Morton, 1991). Koalas, kangaroos, wombats, parrots, cockatoos, lyrebirds, even tree frogs and frillneck lizards, are now familiar and attractive icons of a homeland Australians take pride in.

An Australian journalist comments:

The renaissance of Aboriginal culture and heritage is another sign of growth and maturity. So, too, on a more mundane level, is the popularity of native plants in suburban gardens. What was once alien is now our own (Legge, 1994, p. 10).

Changes in the Australian concept of citizenship have paralleled this geographical shift in perspectives on native plants and animals. Before the introduction of the Nationality and Citizenship Act of 1948, all Australians were simply British subjects (Australian Bureau of Statistics, 1999). Australian-born people are now automatically Australian citizens, and residents born overseas can become citizens provided they satisfy the necessary criteria and are prepared to take the required steps. Now, there are moves for Australia to become a republic, freeing itself of formal British ties altogether. 
This shift in perspectives is summarized in Figure 1. The shift can be cited as evidence that a form of 'ecological nationalism' has emerged among non-indigenous Australians (Dunlap, 1993; Aslin, 1996). This ecological nationalism replaces the 'ecological imperialism' of the early British settlers (Crosby, 1986; Heathcote, 1972).

\section{Figure 1}

Shifts in perceptions of exotic and native animals among AngloAustralians since British settlement of Australia began in 1788. "In this context 'exotic' refers to unfamiliar to the original British settlers.

seterlers.

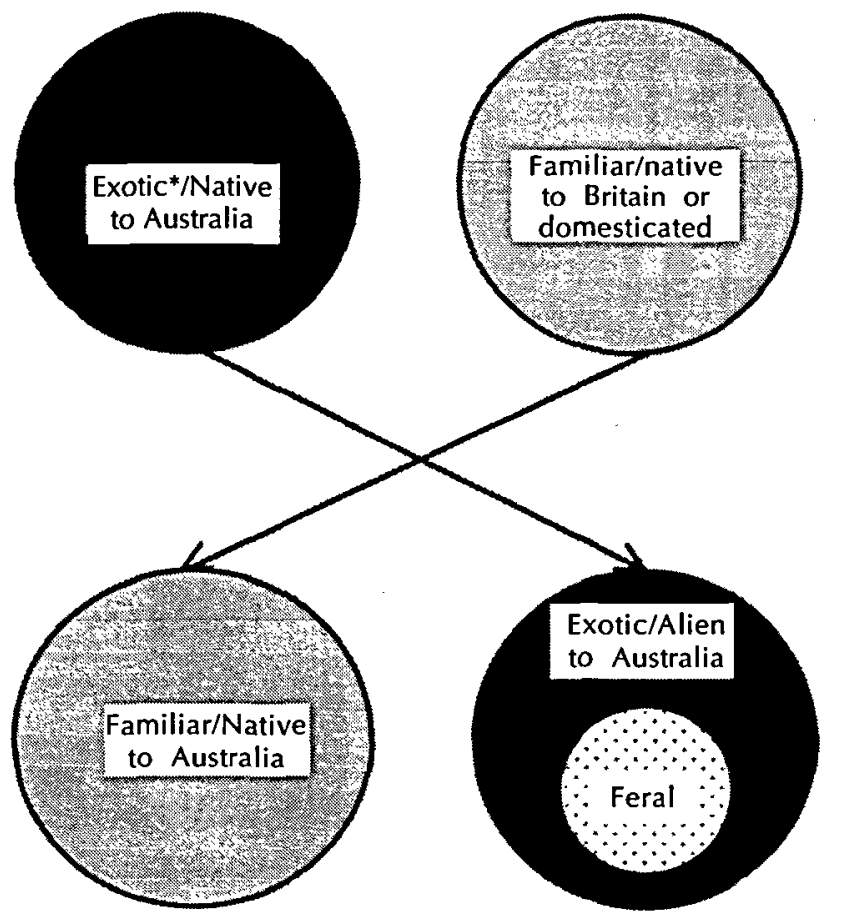

Perceptions in 1788 - the view from Britain

Perceptions today - the view from Australia

Regarding Aboriginal categories, the Aboriginal people of central Australia, for example, do not normally use the terms 'exotic', 'native' or 'feral' to describe animals. However, Aboriginal people recognize that most animals called 'feral' by Anglo-Australians are newcomers to their lands. In her interviews with Aboriginal people from northern Australia, Deborah Bird Rose found that discussion of feral animals in relation to native animals often revealed that the people made a distinction between introduced animals which had no Dreaming and native animals which had $a$ Dreaming 
(Rose, 1996). However, among the Arrernte people of the Northern Territory (whose country runs from north of Alice Springs to south of the Finke River and from Papunya in the west to Atula in the east), Bruce Rose found that:

Many of the people spoken to thought of feral animals as being "-arenye" (belonging to the country) as opposed to "ulerenye" - (a stranger to the country). While it was recognized that these animals had once been "ulerenye" on the whole they now had the status of "-arenye" (Rose, 1995, p. 109).

In other words, for these Aboriginal people, some species introduced since European settlement have already achieved the status of belonging to country.

As Bruce Rose reports:

... feral animals were seen as 'belonging to the country' because they had 'settled down and bred up here' but their numbers were seen as being too high, 'too many animals now they're breeding up' (Rose 1995, p. 112).

The criteria for belonging to country used here are very different from those used by Australian biologists to decide whether or not a species is native to Australia. Criteria used by biologists require an abstract scientifically- and historically-informed judgement to be made about whether or not the species in question evolved in Australia or reached the continent without human aid.

Management of feral animais and responses to species' losses

Differing perceptions of and judgements about feral animals may have direct management implications. For example:

While European land managers and conservationists tend to see feral animals as an environmental problem Aboriginal people do not necessarily share this approach. Many Aboriginal communities see feral species as an important resource for food, employment and recreation (Central Land Council, 1993, p. 44).

Rather than simply try and eradicate a feral species, Aboriginal people may establish and manage feral animal harvesting programs. For example, they may use wild camels for tourism, live export, and human consumption as a viable alternative to beef cattle. Other examples of Aboriginal commercial uses of feral species are given in O'Brien (1992), Ramsay (1994), and Davies, Higginbottom, Noack, Ross \& Young (1999).

\section{Furthermore:}

... feral species have become an important component of subsistence activities. Some of these species are replacing rare or extinct native prey in the diet (for example, the rabbit (Oryctolagus cuniculus) replaces the bilby (Macrotis lagotis) and other native species in the 
arid zone); others, such as the larger, hard-hoofed animals (for example, buffalo (Bubalis bubalis), are a totally new category and can be harder to hunt than native species (Bomford \& Caughley, 1996, p. 20).

Anglo-Australians, particularly wildlife biologists, often believe that feral animals have had major impacts on indigenous species. Some Aboriginal people may share this view but others do not distinguish between the impacts of feral and native animals. Attitudes and beliefs about feral animals vary between Aboriginal groups, as noted by Altman, Bek \& Roach (1996). Many Aboriginal people are happy that feral animals can be used to provide economic and employment benefits for their communities. In such cases, Aboriginal people may become actively involved in commercial or subsistence use of feral animals and there is a partial convergence between their interests and those of western wildlife biologists or environmentalists:

Aboriginal communities have also become involved in the control of feral species ... these species have become integral to some Aboriginal subsistence economies ..., especially in areas where many native prey are now extinct. For example, at $A[u]$ rukun on Cape York [northern Queensland], native subsistence species have declined and pigs have become a major source of protein, the $\mathrm{A}[\mathrm{u}]$ rukun Community Incorporated have had to strike a balance between leaving enough pigs for local consumption and taking enough for environmental protection ... This kind of trade-off will increasingly become a part of environmental management (Bomford \& Caughley, 1996, pp. 24-25).

In general, however, Aboriginal people are against killing feral animals simply as an environmental control measure (Rose, 1995). They also may not believe that introduced species have supplanted or caused the extinction of native ones. In fact:

[Extinction] appears to have little direct meaning to many indigenous Australians. It is not that people have not noticed that animals and plants are missing; many have seen this and been struck with worry and grief. But instead of concluding that an extinction has occurred, they tend to draw other inferences (Rose, 1995, p. 84).

They may conclude that the animals have gone to another country. 'In olden times there were lots of those animals, but they have gone, maybe to Brisbane, maybe to Sydney' (Rose, 1995, p. 89). Why would they conclude this? Perhaps because:

Sometimes those whitefellas bring them back to show us but they dead ones, they got them in box [museum specimen cases], they got them now too I reckon, they took them away from our country (Rose 1995, p. 89). 
Or because, 'Those animals went away down the Dreaming trails, they still there at the end' (Rose, 1995, p. 89).

However, because of their concerns about the disappearance of important species from their country, some Aboriginal communities have joined wildlife biologists in conservation and re-introduction programs:

Aborigines are employed in wildlife conservation programs such as the one run by the Western Australian Department of Conservation and Land Management. Aboriginal peopleare particularly interested in this type of work because it is culturally appropriate and in tune with their aspirations ... It also encourages younger Aborigines to value traditional knowledge and culture ... Aboriginal knowledge has been invaluable for fauna surveys and providing information on species ecology ... Aboriginal communities are often ideally placed to participate in rehabilitation programs for rare and endangered species as evidenced by Tanami Desert people's involvement with programs for the mala or rufous hare-wallaby (Lagorchestes hirsutus) and the bilby ... (Bomford \& Caughley, 1996, p. 24).

In cases like these, shared interests between Aboriginal people and wildlife biologists can lead to cooperative wildlife management across cultural boundaries.

Wild and tame in law and custom

A second example relates to how animals are classified in AngloAustralian common law as compared with Aboriginal customary law.

While Anglo-Australian culture does have a range of attitudes and value-orientations towards wild life, in some respects like Aboriginal culture there is 'common law' which reflects a social consensus about appropriate behavior (although this law sometimes seems to preserve historical judgements rather than ones more appropriate to present-day society). In Australian common law, derived from its British counterpart, animals are divided into two categories: ferae naturae (wild by nature e.g. a wombat), and mansuetae naturae (tame by nature e.g. a dog). Feral animals are a subclass of the latter since some legislation, such as the Northern Territory Pastoral Land Act 1996 defines 'feral animal' as 'an animal of a kind introduced into Australia since 1787 that is living in a wild state'. Thus European red foxes (Vulpes vulpes) become mansuetae naturae rather than ferae naturae. The unspoken (and incorrect) assumption is that all the animals introduced into Australia since European settlement began have been domesticated ones.

These legal distinctions are used to settle property disputes, negligence cases, and other cases where a relationship between one or more people and one or more animals needs to be resolved. For example, a person may be 
responsible for his or her mansuetae naturae dog causing an injury to another person but not for an injury caused by a ferae naturae wombat on his or her property.

Such legal concepts reflect to some degree a set of social concepts about the relationships between humans and animals, but the legal concepts do not exhaust the social concepts. That is, the legal concepts accord with the social concepts to the extent that domesticated animals are held to belong to someone, or someone is held to be responsible for the well-being of those animals. But feral and wild animals do not belong to anyone and for the most part no-one is held to be responsible for them.

How does this compare with Aboriginal customary law? First, it should be pointed out that 'wild' and 'wildlife' are essentially inappropriate concepts to Aboriginal people. To Aboriginal people living in their country, the 'wild' is the 'tame and familiar' - essentially nothing in country is wild as it is all the result of continuing Aboriginal cultural practices as well as the original creative acts of the ancestral beings. Unlike Anglo-Australian common law, Aboriginal customary law is not written down, nor is common to all Aboriginal people. But in contrast to the distinctions made and responsibilities apportioned in Anglo-Australian common law, Aboriginal Australians are responsible under their customary law for animals and plants that have been given significance by their ancestral beings. They can be held accountable for failing to perform the appropriate ceremonies to ensure that these animals and plants, particularly totemic species, survive and flourish.

Figure 2 summarizes some comparisons between Anglo-Australian and Aboriginal categories for wildlife.

The case of the cat

Perhaps the prime example of contrasts between Aboriginal and AngloAustralian perspectives is the case of the feral cat (Felis catus) in central Australia. Unlike Anglo-Australians, Aboriginal people see the origin of feral cats as being different from that of other feral species. Aboriginal people consistently maintain that cats have been in central Australia for a long time and many Aboriginal people say that they came from the west. A number of Bruce Rose's informants told him that the feral cat has a Dreaming in their country (Rose, 1995). This information has led to speculation that cats colonized the centre as result of seventeenth century Dutch shipwrecks on Australia's west coast or landings by Macassan fishing vessels (Cohen, 1992; Australian Nature Conservation Agency, undated). The feral cat has taken on an important role in Aboriginal diets in many areas and its consumption is seen by many Aboriginal people to have medicinal qualities. At Atitjere (the Hartz Range in the Northern Territory, northeast of Alice Springs and 
Figure 2

Comparisons of some common language Anglo-Australian and Aboriginal categories for wildlife. This diagram should not be taken to imply that Aboriginal people necessarily regard all feral animals as 'settled down' in their country. Under Anglo-Australian common law, 'feral' animals are a subset of 'tame by nature' animals (mansuetae naturae) and are not defined as being 'wild' in the common language sense.

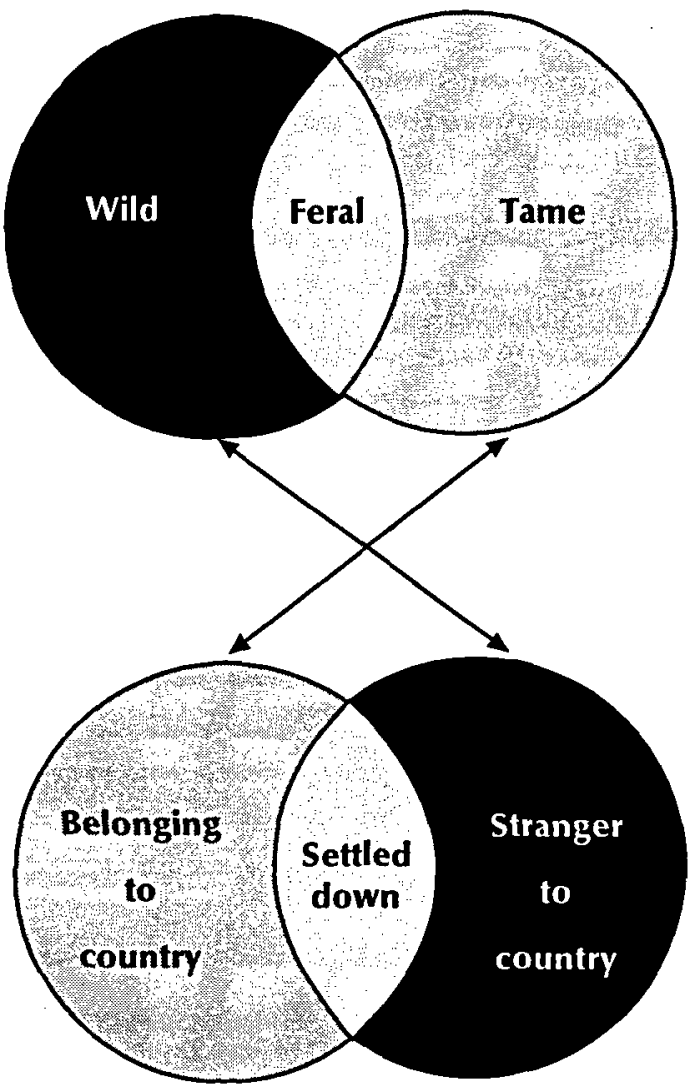

Anglo-Australian

Aboriginal

in Eastern Arrernte country), people reported that their 'country has a Pussy Cat Dreaming. We don't eat them now, we just keep them for pets' (Rose, 1995, p. 115).

In other countries, Antarrengeny for example (lying north of Alice Springs and northeast of Ti Tree), Aboriginal people eat cats - 'pussy cats, they're good meat, we catch them and eat them' (Rose, 1995, p. 115). 
Kingsley Palmer in his book, Swinging the billy: Indigenous and other styles of Australian bush cooking, declines to provide recipes for feral cats:

In deference to cat lovers, especially my wife and our two cats, Malcolm and Myrtle, there is no recipe for wild cat (putjikata: pussy cat), but it is eaten in desert areas of Australia. I tried to eat one only once, in the Great Sandy Desert [of central Western Australia]. It was so tough that any taste was lost on me. Like most other meat dishes it is gutted and cooked on an earth oven (Palmer, 1999, p. 39).

In contrast to many indigenous people, Western wildlife biologists and conservationists often single feral cats out as a major threat to native animals and stress the need for them to be controlled. Conservationist and former Federal Environment Minister, Barry Cohen, quotes Alan Newsome of the CSIRO Division of Wildlife and Ecology:
"Nothing good can be said of them," he says, pointing out there is a very fine line between domestic and feral cats. He maintains that while the impact of feral cats on mainland Australia has not been measured, they have caused a number of species to become extinct on offshore islands (Cohen, 1992, p. 10).

Information on feral animals distributed by the Federal Government's Australian Nature Conservation Agency (now the Biodiversity Group of Environment Australia), reports that feral cats caused the extinction of a subspecies of the red-fronted parakeet (Cyanoramphus novaezelandiae) on Macquarie Island, an Australian sub-Antarctic territory. It also reports that feral cats killed many captive-bred malas (rufous hare-wallabies, Lagorchestes hirsutus) released in the Tanami Desert of the western Northern Territory as part of a re-introduction program for this endangered species (Australian Nature Conservation Agency, undated). There is little question that cats, both domestic and feral, kill large numbers of native animals in Australia, but the evidence for them causing species' extinctions seems thin - and of course it is extremely difficult to get conclusive evidence of this kind. While there is clearly large variation, it has been suggested that Australian feral cats may kill as many as 1000 vertebrate animals (native or introduced) per year, whereas domestic cats may kill around 25 per year (Hill, 1996).

However, in attempting to eradicate or control feral cats, wildlife biologists and conservationists run the risk of raising the ire of the many Australian cat lovers who have different feelings of responsibility for cats and find it difficult to change their attitudes because the label 'feral' is applied.

If good evidence is found that the cat has been living in a wild state in Australia for considerably longer than previously thought, how would this affect judgements of feral cats and how they should be treated? They would no longer fit in the category 'feral' under the definition used in the Northern 
Territory Pastoral Land Act mentioned above. Could they ever attain the status of a native animal in a way comparable to the way some Aboriginal people have accepted them as belonging to country and accorded them totemic status?

\section{Summarizing cultural comparisons}

Table 1 provides a brief summary of some of the major differences between the two contrasting cultural traditions, as highlighted in this paper. It is modified from a similar summary used by anthropologist Rosemary Hill and her indigenous colleagues to compare concepts used by the KukuYalanji Aboriginal people of the Wet Tropics World Heritage Area in north Queensland, and those used by the natural resource managers employed by the Federal Government's Wet Tropics Management Authority (Hill, Baird \& Buchanan, 1999).

\section{Table 1}

Comparisons of Aboriginal and Anglo-Australian cultural conceptions of wildlife management (modified from Hill et al., 1999)

Wildlife management aspect Aboriginal concepts Anglo-Australian concepts

\begin{tabular}{lll}
\hline Goals & Caring for country/be & Biodiversity conservation, \\
& longing to country. & sustainable land management \\
& maintaining culture & ecologically sustainable \\
and group identity & development
\end{tabular}

Knowledge base

Political, legal and moral authority

Management concepts and techniques

Knowledge transfer

Categories and judgements about species
Traditional Aboriginal knowledge systems

Elders and councils, customary law, group responsibility and management rights, the 'Dreaming'

Totemic relationships and traditional ceremonies, rituals, traditional techniques

Word of mouth, story telling. listening to elders

Belonging to country versus stranger to country, gone from country
Western knowledge systems and world views, science and technology

Parliaments, common law. other Commonwealth and state laws, government obligations and commitments

Plans and strategies, western scientific techniques

Childhood and family training, formal education, corporate and organizational cultures, mass media

Native versus feral/exotic, wild versus tame/domestic, species' extinctions 


\section{Conclusions}

Aboriginal people do not necessarily divide animals into the categories used by Anglo-Australians, and accordingly the way they value and treat animals cuts across these categories. But in both indigenous and nonindigenous cultures, the process of naming and caregorizing (even though sometimes based on shaky or illogical grounds and subject to change), invokes value judgements and norms for behavior towards species according to how they are categorized. If for some reason the categorization of a particular species is revised, that species may need to be treated differently as a result. A change in social meaning may lead to a value, attitudinal, and behavioral shift. The case of the feral cat in Australia demonstrates these points and how they have different implications in Aboriginal and AngloAustralian culture.

This is one form of evidence showing that people's perspectives on wildlife are inescapably bound to their world views, cultural assumptions, knowledge, and symbolic systems. These perspectives are culturally-relative and often conflicting between different cultures, societies, and social groupings within societies. The comparisons made here between the wildlife values and attitudes of Aboriginal and Anglo-Australians show how these values and attitudes relate to characteristic social and cultural perspectives. They demonstrate how wildlife attitudes and values are specific to particular cultures, societies, places and times.

Cross-cultural and historical comparisons like those made in this paper illustrate diverse social and cultural understanding of the environment as referred to earlier in the Introduction, and demonstrate how considering diverse knowledge systems can inform dialogues and decision-making on wildlife and other natural resource issues. These comparisons also help provide social perspective on the western scientific knowledge systems, biological concepts, and often-unexamined assumptions that underpin much formal wildlife policy and practice in western nations. Through comparisons like these, wildlife professionals can develop an awareness of their own cultural and social situations and their implications for future human-wildlife interactions.

\section{References}

Aboriginal and Torres Strait Islander Commission (1997). National Aboriginal and Torres Strait Islander rural industry strategy. Canberra: Aboriginal and Torres Strait Islander Commission \& Department of Primary Industries and Energy.

Altman, J., Bek, H. \& Roach, L. (1996). Use of wildlife by indigenous Australians: Economic and policy perspectives. In Sustainable use of wildlife by Aboriginal people and Torres Strait Islanders. Eds M. Bomford \& J. Caughley. Canberra: Australian Government Publishing Service. Pp. 77-94. 
Altman, J. C., Roach, L. M. \& Liddle, L. E. (1997). Utilization of native wildlife by indigenous Australians: Commercial considerations. Discussion Paper no. 135/1997. Canberra: Centre for Aboriginal Economic Policy Research, The Australian National University.

Aslin, H. J. (1996). Speaking of the wild: Australian attitudes to wildlife. Unpublished $\mathrm{PhD}$ thesis, The Australian National University, Canberra.

Australian Bureau of Statistics (1999a) Australia now - a statistical profile. Population. The Aboriginal and Torres Strait Islander population. [Data from the 1996 Census of Population and Housing.] htrp://www.abs.gov.au

Australian Bureau of Statistics (1999b) Australia now - a statistical profile. Population. Citizenship. [Data from the 1996 Census of Population and Housing.] http:/l www.abs.gov,au

Australian Bureau of Statistics (1999c). Australia now - a statistical profile. Population. The Aboriginal and Torres Strait Islander population. [Data from the 1996 Census of Population and Housing.] http://www, abs.gov.au

Australian Nature Conservation Agency (undated). Feralanimals in Australia. Canberra: Australian Nature Conservation Agency. [Series of information leaflets about feral animals.]

Bennett, D. H. (1995). Issues in the sustainable use of wildlife by indigenous peoples: the Convention on Biological Diversity and native title. Pp. 60-68 in Conservation through sustainable use of wildlife. Ed. G. C. Grigg, P. T. Hale \& D. Lunney. Brisbane: Centre for Conservation Biology, University of Queensland.

Bomford, M. \& Caughley, J. (1996). Sustainable use of wildlife by Aboriginal people and Torres Strait Islanders. Canberra: Australian Government Publishing Service.

Bulbeck, C. (1996). Authentic animal encounters: dolphins, sea lions and others. Unpublished lecture presented in 'Widening your horizons' series, 6 July 1996. Griffith University, Brisbane.

Central Land Council (1993). Annual Report 1992-93. Alice Springs: Central Land Council.

Cohen, B. (1992). Killers at large. The Australian Magazine, The Weekend Australian, 28-29 March 1992, 9-12.

Collins, J., Klomp, N. \& Birckhead, J. (1996). Aboriginal use of wildlife: past, present, future. In Sustainable use of wildlife by Aboriginal peoples and Torres Strait Islanders. Eds M. Bomford \& J. Caughley. Canberra: Australian Government Publishing Service.

Crosby, A. (1996). Ecological imperialism. New York: Cambridge University Press.

Davies, J., Higginbottom, K., Noack, D., Ross, H., \& Young, H. (1999). Sustaining Eden: Indigenous community wildlife management in Australia. International Institute for Environment and Development Biodiversity Group 'Evaluating Eden' series. London: IIED.

Dodson, M. (1997). Land rights and social justice. In Our land our life: Land rightspast, present and future. Ed. Galarrwuy Yunupingu. St. Lucia, Brisbane: Universiry of Queensland Press.

Dunlap, T. R. (1993). Australian nature, European culture: Anglo settlers in Australia. Environmental History Review, 17(1), 25-48.

Flannery, T. F. (1994). The future eaters: An ecological history of the Australasian lands and people. Chatswood: Reed Books.

Fox, W. (1990). Toward a transpersonal ecology. Boston and London: Shambhala.

Giddens, A. (1984). The constitution of society: Outline of the theory of structuration. Cambridge: Polity Press.

Glacken, C. (1967). Traces on the Rhodian shore: Nature and culture in western thought from ancient times to the end of the eighteenth century. Berkeley: University of California Press. 
Heathcote, R. L. (1972). The visions of Australia 1770-1990. In Australia as human setting, ed. A. Rapoport. Sydney: Angus \& Robertson.

Hill, R. (1996). Feral cats pose threat to native mammals and birds. Press release from Australian Federal Minister for the Environment's Office, Canberra, 23 September (cited in TED Case Studies, Case Number 396, http://www.american.edu/projects/mandala/ TED/CATS.HTM)

Hill, R., Baird, A., \& Buchanan, D. (1999). Aborigines and fire in the Wet Tropics of Queensland, Australia: Ecosystem management across cultures. Society \& Natural Resources 12, 205-223.

Kellert, S. R. (1976). Perceptions of animals in American society. Transactions of the North American Wildlife and Natural Resources Conference, 41, 533-546.

Kellert, S. R. (1993). Attitudes, knowledge, and behavior toward wildlife among the industrial superpowers: United States, Japan, and Germany. Journal of Social Issues, 49(1), 53-69.

Kellert, S. R. and Berry, J. K. (1980). Knowledge, affection and basic attitudes toward animals in American society. Washington, D.C.: United States Department of the Interior, Fish and Wildlife Service and Yale School of Forestry and Environmental Studies.

Kellert, S. R. and Clark, T. W. (1991). The theory and application of a wildlife policy framework. In Public policy issues in wildlife management. Ed. W. R. Mangun. Pp. 17-36.

Kellert, S. R. \& Wilson, E. O. (1993). The biophilia bypothesis. Washington, D.C.: Island Press.

Kohen, J. (1995). Aboriginal environmental impacts. Sydney: University of New South Wales Press.

Krutilla, J. V. \& Fisher, A. C. (1985). The economics of natural environments: Studies in the valuation of commodity and amenity resources. Washington, DC: Resources for the Future.

Legge, K. (1994). Rediscovering Australia. The Australian Magazine, The Weekend Australian, 22-23 January 1994, 8-14.

Lines, W. J. (1991). Taming the Great South Land: A history of the conquest of nature in Australia. Sydney: Allen \& Unwin.

Macquarie Concise Dictionary (1988). Second edition. General eds A. Delbridge and J. R. L. Bernard. Sydney: The Macquarie Library.

Marshall, A. J. (ed.) (1966). The great extermination: A guide to Anglo-Australian cupidity, wickedness and waste. London and Melbourne: Heinemann.

Midgley, M. (1978). Beast and man: The roots of human nature. Hassocks: Harvester.

Morton, J. (1991). Black and white totemism: conservation, animal symbolism, and human identification in Australia. In Australian people and animals in today's dreamtime. Ed. D. B. Croft. New York: Praeger. Pp. 21-51.

O'Brien, P. (Ed.) (1991). Wildlife use and management. Report of a workshop for Aboriginal and Torres Strait Islander people. Canberra: Bureau of Rural Resources.

Orlans, F. B. (1993). In the name of science: Issues in responsible animal experimentation. New York: Oxford University Press.

Palmer, K. (1999). Swinging the billy: Indigenous and other styles of Australian bush cooking. Canberra: Aboriginal Studies Press.

Parsons, T. (1991). The social system (with a new preface by B.S. Turner). London: Routledge. [First published 1951.]

Pearce, D. W. \& Turner, R. K. (1990). Economics of natural resources and the environment. Hertfordshire: Harvester Wheatsheaf.

Pepper, S.C. (1957). World hypotheses: $A$ study in evidence. Berkeley and Los Angeles: University of California Press. [First published 1942.]

Ramsay, B. J. (1994). Commercial use of wild animals in Australia. Canberra: Bureau of Resource Sciences. 
Roberts, B. (1995). The quest for sustainable agriculture and land use. Sydney: University of New South Wales Press.

Rolls, E. C. (1969). They all ran wild. Sydney: Angus \& Robertson.

Rose, B. (1995). Land management issues: attitudes and perceptions amongst Aboriginal people in central Australia. Alice Springs: Central Land Council.

Rose, D. B. (1996). Nourishing terrains: Australian Aboriginal views of landscape and wilderness. Canberra: Australian Heritage Commission.

Schulz, W. (1986). Attitudes toward wildlife in West Germany. In Valuing wildlife. Ed. D. Decker \& G. Goff. Boulder: Westriew. Books.

Saul, J. R. (1997). The unconscious civilization. Ringwood, Melbourne: Penguin

Stanner, W. E. H. (1960). On Aboriginal religion. Oceania, 30, 245-278.

Stanner, W. E. H. (1979). White man got no Dreaming. Canberra: Australian National University Press.

Tober, J. (1989). Wildlife and the public interest: Nonprofit organizations and federal wildlife policy. New York: Greenwood.

Sylvan, R. \& Bennett, D. H. (1994). The greening of ethics. Cambridge and Tucson: White Horse Press and the University of Arizona Press.

Von Sturmer, J. (1978). The Wik Region: Economy, territoriality and totemism in Western Cape York Peninsula, North Queensland. Unpublished $\mathrm{PhD}$ thesis, University of Queensland, Brisbane.

Young, E. A., Ross, H., Johnson, J. \& Kesteven, J. (1991). Caring for country: Aborigines and land management. Canberra: Australian National Parks and Wildlife Service. 